\title{
Customer's Usage of Cashless Banking Services -with Special Reference to Puducherry (U.T)
}

\author{
S. Thirumal
}

\begin{abstract}
Cashless Banking is a designate or of financial transaction handled by means of credit cards, bank transfer, and cheques, with no exchange of bills or coins. The recent evolution of technology for financial transactions poses interesting questions for policy makers and financial institutions regarding the fitness of current institutional arrangements and availability of instruments to guarantee financial stability, effectiveness \& efficiency of economic policy. This study aims to find out how the socio economic conditions of the respondents influence the proper and prompt use of various services. 135 sample customers from Puducherry (U.T) were chosen for the study. The findings show that the respondents' education qualification and the type of account (Savings, fixed, recurring and current account) are moderately correlated with the use of different services provided by the bank.
\end{abstract}

Keywords : Cashless banking services, Education, duration of relationship with bank, Payment Purpose.

\section{INTRODUCTION}

Cashless Banking is a designate or financial transaction handled through credit cards, bank transfer, and cheques with no exchange of bills or coins. Money is transformed through a system in which people pay for purchase through bank cards, moving money over the interest instead of using cash in the form of coins and paper currency. A main benefit of the cashless system is the elimination of manual works in connection with counting and handling cash. Around $11 \%$ of urban Indian households have embraced cashless transaction, but penetration of cashless transaction is still meager ( 0.43 percentage), according to a report by Indian Development Fund (IDF) and Internet and Mobile Association of India (IAMAI).

According to the study with a cash circulation of over rupees one lakh crore of transfer of 1 percentage moving to cashless transactions can reduce cash distribution just by rupees 1000 crore. A modest growth of cashless transactions by $5 \%$ will save the country more than rupees 5000 crore annually.

As the electronic payment which is the proper channel to implement effective cashless transactions would attract more number of people into the fields of formal economy, such a transfer of cashless transactions from cash transactions has to be encouraged.

Revised Manuscript Received on December 05, 2019.

* Correspondence Author

Dr. S. Thirumal, Assistant Professor of Commerce, The Tamil Nadu Dr. Ambedkar Law University, School of Excellence in Law, Chennai, India. E-mail: thirumallecturer@gmail.com
Besides helping in the saving of money spent on printing materials and time spent on accounting, cashless banking ensures reduction of managing and moving currency in the country. It is the exchange of funds by cheque, debit or credit card, or electronic channels rather than through hot cash.

As E-payments will carry more people into the folds of proper economy, there is a require to dis-incentive cash and go faster acceptance of E-payment channels. While the electronic payments industry continue to guarantee accessibility of e-payment instruments to more and more Indians, there is no encouragement for them to use their card in lieu of cash. Establishment of an electronic payment network based on the achievement of multiple factors like Merchants, Point Of Sale (POS) infrastructure, E-Wallet, mobile phone Applications, Net Banking and the like.

Cashless transfer is nothing but an electronic or digital transaction of a resources with the help of net banking, credit card, etc. The shopping payments of bills, transactions and management of all the finances from home, office can easily and quickly be carriedout with the smart phone. It does not only ease our life but also authenticate and formalize our transactions.

E-transactions also help in curbing its transportation. Its ingeniosity is doubtful only when it comes to cyber scam and hack. In the third world country, cashless transaction system is not pervasive for to lack of education and technology gap which is actually a matter of concern and must be addressed by government or financial institutions or both.

\section{STATEMENT OF THE PROBLEM}

The recent advancement of technology used in financial transactions poses interesting questions for policy makers and financial institutions regarding the suitability of current institutional arrangements and accessibility of instruments to guarantee financial stability, effectiveness \& efficiency of monetary policy. Over the course of history, different forms of payment systems have been in continuation. In the beginning, trade by barter was common. However, the problems of barter such as the double coincidence of wants necessitated the introduction of different forms of money. Nevertheless, pundits have been predicting the complete demise of study instruments and the emergence of potentially superior substitute for cash or monetary exchanges, that is, cashless society.

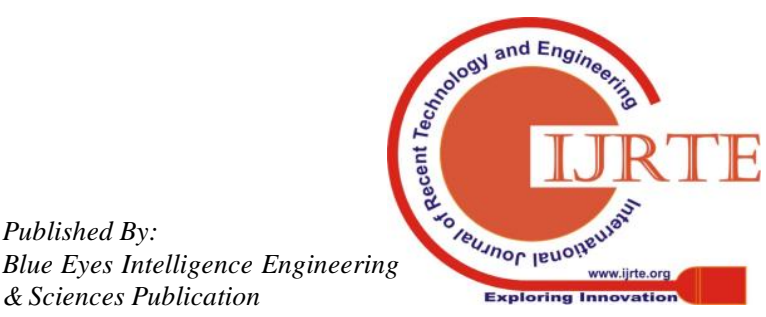




\section{IMPORTANCE OF THE STUDY}

The usage of cashless banking in beneficial to customers. The cashless banking impacts the life style at global level.

The Cashless banking services through which people effect transactions include ATM Services, Internet Banking Services, Mobile Banking, NEFT/RTGS, Debit and Credit and Immediate Payment Services (IMPS)

\section{OBJECTIVES OF THE STUDY}

The following are the objectives of the present study:

1. To study the socio economic conditions of the respondents.

2. To examine the various services used by the respondents

\section{METHODOLOGY}

The study was exploratory in nature based on survey method. The primary data were collected through personal contacts, the sample frame were the individual customers of banks living in Pondicherry (UT). 135 Individual respondents chosen as the sample selected with the help of Purposive sampling technique. The collected data were analyzed with statistical tools like percentage analysis, Correlation and significant difference analysis with the help of SPSS.

\section{RESULTS OF THE STUDY}

\section{A. Socio-economic profile of the respondents}

Gender:48.90\% of the Respondents are Males and $51.10 \%$ are Females. Age: $4.40 \%$ of the Respondents are in the age group of 20 years, $70.40 \%$ in the age group of $21-40$ years and $25.20 \%$ are in the age group of above 40 years. Education:20\% of the Respondents have completed Matric/SSLC, $23 \%$ have completed, and $31.80 \%$ are undergraduates. $15.60 \%$ are post graduates and $9.60 \%$ have undergone other courses. Employment: $29.60 \%$ of the Respondents are employed in public sector $70.40 \%$ are working in private sector. Income (monthly) : $31.10 \%$ of the respondents in study area have a monthly income of less than 20,000, $43 \%$ earn between 20,001-50,000, 17\% earn between $50,001-80,000$ and $8.90 \%$ have a monthly income of more than 80,000 .

Account type: invariably all the respondents operate savings $\mathrm{a} / \mathrm{c}$, as per the norms of the banks 9.60 of the respondents operate current account, $1.50 \%$ have recurring a/c and $6.70 \%$ maintain TDR. Length of Association with Banks: $5.90 \%$ of the respondents of study area are associated for less than one year. $12.60 \%$ of the respondents of the selcted study area are associated with the bank for 1 to 3 years, $36.30 \%$ for 3 to 5 years and $45.20 \%$ for more than 5 years. Account Mode: $88.90 \%$ of the respondents operate individual account while remaining $11.10 \%$ operate joint account.

\section{B. Type of banking services used by the respondents}

Purpose of using Banking Services:47.40\% of the
Respondents use for fund transfer, $10.40 \%$ utilize quick pay services, $8.90 \%$ use recharge services, $11.10 \%$ utilize bills payments, $3.70 \%$ use e-locker. It is thus found that a majority of Respondents use fund transfer. Technology: $14.10 \%$ of the respondents utilize unified payment interface, $45.20 \%$ use mobile payment, $9.60 \%$ utilize FIS banking technology and $31.10 \%$ use other technological services. Thus, the highest percentage of the respondents uses mobile payment. Regarding mode of transactions a majority, that is, two thirds of respondents still continues to transfer through cash while one third have shifted to cashless transactions.

Correlation analysis of socio economic conditions with their different type of Banking services using by the respondents.

The age and type of account (Single or Joint account) does no correlate with the different services provided by the bank. Length of association with banks and occupation is less correlated with the different services provided by the bank. The respondent's educational qualification and the type of account (Saving, fixed, recurring and current account) is moderately correlated with the services provided by the bank.

\section{Analysis of significant difference in the use of banking services}

Table showing the results of the analysis of significant difference in the use of banking services

Table -1: Analysis of significant difference in the use of banking services

\begin{tabular}{|l|c|c|c|l|}
\hline \multirow{2}{*}{ Variable } & \multicolumn{3}{|c|}{ Test value } \\
\cline { 2 - 5 } & F & Sig. & Result & \multicolumn{1}{c|}{ Interference } \\
\hline $\begin{array}{l}\text { Purpose using } \\
\text { bank account }\end{array}$ & 3.244 & .002 & $\begin{array}{c}\text { Accept } \\
\text { H1 }\end{array}$ & $\begin{array}{l}\text { There is a significant difference in } \\
\text { their purpose of using the bank } \\
\text { account }\end{array}$ \\
\hline $\begin{array}{l}\text { Type of } \\
\text { Technology } \\
\text { using in bank } \\
\text { transaction }\end{array}$ & 1.143 & .032 & Accept & $\begin{array}{l}\text { There is a significant difference in } \\
\text { their use of Technology in bank } \\
\text { transaction }\end{array}$ \\
\hline $\begin{array}{l}\text { Frequency of } \\
\text { usage } \begin{array}{l}\text { Fage } \\
\text { transaction }\end{array}\end{array}$ & 2.421 & .011 & Accept & $\begin{array}{l}\text { There is a significant difference in } \\
\text { the frequency of transaction }\end{array}$ \\
\hline $\begin{array}{l}\text { Circumstances } \\
\text { of cashless } \\
\text { bank usage }\end{array}$ & 3.122 & .003 & Accept & $\begin{array}{l}\text { There is a significant difference in } \\
\text { the circumstances of cashless bank } \\
\text { usage }\end{array}$ \\
\hline
\end{tabular}

With regard to the frequency of usage of banking services $23.70 \%$ of respondents use thrice a month while a majority of $43.70 \%$ make a frequent use, that 8 times in a month. $12.60 \%$ of respondents make use of the banking facilities less than 12 times in a month while $14.10 \%$ do so more than 12 times.

\section{LIMITATION OF THE STUDY}

1. The study is focused only Puducherry (U.T)

2. It analyzed only the limited variables and types of services provided by the bank 
3. It examines how the customers utilize these services, how the socio economic profile of the respondents influence their usage of cashless banking services.

\section{CONCLUSION}

Finally, the research concludes that the Cashless Banking Services in Banking System are used by the customers are at a satisfactory level. The individuals have their own perception towards various types of banking services. Cashless Banking Services brings the easiest way of making payments without carrying money, so it is essential for business undertaking and other industries.

Nowadays, Cashless Banking Services begin to occupy the center stage in India. But the majority of the customers are unaware of the cashless banking services. The major factor which would influence the customers to transfer to of cashless banking services is education. So the policy makers and bankers may convene periodical meetings with the customers to enlighten them on the mode of operation and advantages of cashless banking.

\section{REFERENCES}

1. Kamakodi,N (2007), “Customer Preference on e-Banking Services-Understanding through a sample survey of Customers of present day Banks in India", Contributors, Vol. IV, Banknet Publications, pp.30-43.

2. Karthikeyan, K (2007), "Customers' attitude towards technology based services offered by the ICICI bank in Sivakasi - M.Phil Dissertation", ANJA College, Sivakasi.

3. Joshua A.J.Moli and P.Koshi (2005), "Expectations and Perceptions of service quality in old and new generation banks", Indian Journal of Marketing, September, p.16.
4. Srinivasarao.K (2008): "Technology Innovations in Banks", The Indian Banker, December 2008

5. Vimi and Mohd. (2008): "Customers' Satisfaction in Indian Banking Industry: A Study", Journal of Marketing, pp.84-93.

6. Tesfatsion Sahlu Desta (2011): "Perceived Quality of Services Rendered by Commercial Banks: A Case Study of State Bank of India (SBI), Punjab University (PU) Branch, Chandigarh, India", International Journal of Engineering and management sciences, Vol. 2, pp. 25-35.

7. Ravichandran K (2010): "Influence of Service Quality on Customer Satisfaction, Application of SERVQUAL Model", International Journal of Business Management, Vol. 5, pp. 117-124.

8. NaziaNabi (2012): “Customer Expectations of Service Quality: A Study on Private Banks of Bangladesh",World Review of Business Research, Vol. 2,No. 4, pp. $172-186$

\section{AUTHOR PROFILE}

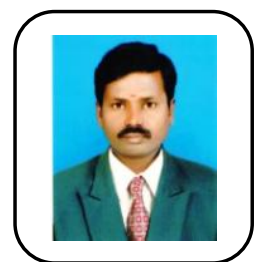

Dr. S. THIRUMAL., M.Com., M.Phil., MBA., PGDCA., Ph.D, Assistant Professor of Commerce School of Excellence in Law, The Tamil Nadu Dr. Ambedkar Law University Perungudi Campus, Chennai - 600113 Number of books published 2, Number of Journals published - 17, Programme organized -8 , Number of organised NSS Camp 1 . Acted as resource persons in conferences -3 , Number of members in Association - 6, Number of Guest lecture delivered 11 , Number of paper presentation in National/ International Conference - 16, Number of Research funding Project Applied - 6 Number of Faculty Development programme attended -9 , Number of attended workshops -13 , Participated in Seminar / Conference / Symposium - 11, Number of Attended National level NSS Camp - 2, Guided Summer Project M.Com (Business Finance) students in Pondicherry University - 8.

\section{APPENDIX}

Table \# 1 Customer's Socio-Economic Conditions

\begin{tabular}{|c|c|c|c|c|c|c|c|}
\hline \multicolumn{2}{|c|}{ Variable } & \multirow{2}{*}{\begin{tabular}{c|}
$\mathbf{N}$ \\
66 \\
\end{tabular}} & \multirow{2}{*}{$\begin{array}{c}\% \\
48.90 \\
\end{array}$} & \multicolumn{2}{|c|}{ Variable } & \multirow{2}{*}{$\begin{array}{c}\mathbf{N} \\
40\end{array}$} & \multirow{2}{*}{$\begin{array}{c}\% \\
29.60\end{array}$} \\
\hline \multirow{3}{*}{ Gender } & Male & & & \multirow{3}{*}{ Employer type } & Public & & \\
\hline & Female & 69 & 51.10 & & Private & 95 & 70.40 \\
\hline & Total & 135 & 100 & & Total & 135 & 100 \\
\hline \multirow{4}{*}{ Age in Years } & $<20$ & 6 & 4.40 & \multirow{5}{*}{ Account type } & Savings & 111 & 82.2 \\
\hline & $20-40$ & 95 & 70.40 & & Current & 13 & 9.60 \\
\hline & $>40$ & 34 & 25.20 & & Recurring & 2 & 1.50 \\
\hline & Total & 135 & 100 & & Fixed & 9 & 6.70 \\
\hline \multirow{6}{*}{ Education } & SSLC & 27 & 20 & & Total & 135 & 100 \\
\hline & H.S & 31 & 23 & \multirow{5}{*}{$\begin{array}{c}\text { Account maintaining } \\
\text { years }\end{array}$} & $<1$ & 8 & 5.90 \\
\hline & U.G & 43 & 31.90 & & $1-3$ & 17 & 12.60 \\
\hline & P.G & 21 & 15.60 & & $3-5$ & 49 & 36.30 \\
\hline & Others & 13 & 9.60 & & $>5$ & 61 & 45.20 \\
\hline & Total & 135 & 100 & & Total & 135 & 100 \\
\hline \multirow{5}{*}{$\begin{array}{l}\text { Monthly Income (In } \\
\text { '000') }\end{array}$} & $<20$ & 42 & 31.10 & \multirow{3}{*}{ Account mode } & Single & 120 & 88.90 \\
\hline & $20-50$ & 58 & 43 & & Jointly & 15 & 11.10 \\
\hline & $50-80$ & 23 & 17 & & Total & 135 & 100 \\
\hline & $>80$ & 12 & 8.90 & & & & \\
\hline & Total & 135 & 100 & & & & \\
\hline
\end{tabular}

Source: Primary Data 
Customer's Usage of Cashless Banking Services -with Special Reference to Puducherry (U.T)

Table \# 2 Various Services Using by the Respondents

\begin{tabular}{|c|c|c|c|c|c|c|c|}
\hline \multicolumn{2}{|r|}{ Variable } & $\mathbf{N}$ & $\%$ & \multicolumn{2}{|c|}{ Variable } & $\mathbf{N}$ & $\%$ \\
\hline \multirow{8}{*}{ Purpose } & Fund Transfer & 64 & 47.40 & \multirow{3}{*}{$\begin{array}{l}\text { Mode of } \\
\text { payment }\end{array}$} & Cash & 88 & 65.20 \\
\hline & Quick Pay & 14 & 10.40 & & Cashless Banking & 47 & 34.80 \\
\hline & Recharge & 12 & 8.90 & & Total & 135 & 100 \\
\hline & Bill Payments & 15 & 11.10 & \multirow{6}{*}{$\begin{array}{c}\text { Frequency } \\
\text { of Using }\end{array}$} & Below 3 times & 32 & 23.70 \\
\hline & E-Locker & 5 & 3.70 & & $4-8$ times & 59 & 43.70 \\
\hline & Services & 10 & 7.40 & & $9-12$ times & 17 & 12.60 \\
\hline & Others & 15 & 11.10 & & $>12$ times & 19 & 14.10 \\
\hline & Total & 135 & 100 & & None of the above & 8 & 5.90 \\
\hline \multirow{6}{*}{$\begin{array}{c}\text { Type } \\
\text { technology }\end{array}$} & Unified Payment Interface & 19 & 14.10 & & Total & 135 & 100 \\
\hline & Mobile Payment & 61 & 45.20 & \multirow{5}{*}{$\begin{array}{c}\text { Usage of } \\
\text { cashless } \\
\text { bank }\end{array}$} & Fund Transfer & 42 & 31.10 \\
\hline & FIS Banking Technology & 13 & 9.60 & & Retail Purchases & 18 & 13.30 \\
\hline & Others & 42 & 31.10 & & Online Shopping & 51 & 37.80 \\
\hline & \multirow{2}{*}{ Total } & \multirow{2}{*}{135} & \multirow{2}{*}{100} & & Others & 24 & 17.80 \\
\hline & & & & & Total & 135 & 100 \\
\hline
\end{tabular}

Source: Primary data

Table \# 3 Correlation between Socio-Economic Characters and Usage of Banking Services

\begin{tabular}{|c|c|c|c|c|}
\hline Variable & Purpose & Technology & Frequency of usage & Usage of cashless bank \\
\hline Age & .024 & .452 & .362 & .563 \\
\hline Education & .342 & .634 & .547 & .639 \\
\hline Occupation & .132 & .221 & .342 & .321 \\
\hline Account type & .541 & .445 & .321 & .332 \\
\hline Years usage & .011 & .212 & .111 & .001 \\
\hline Account usage & .021 & .002 & .031 & .004 \\
\hline
\end{tabular}

Source: Primary data 